\title{
The Relationship Between Saving and Credit from a Schumpeterian Perspective
}

\author{
Giancarlo Bertocco
}

\begin{abstract}
Mainstream economic theory underlines the close relation between saving decisions and credit supply: the saving decisions determine the credit supply and thus the investment flow carried out by all firms. This paper has two objectives: 1) to highlight the theoretical limits of this causal sequence on the basis of the arguments developed by Schumpeter, who instead maintains that in a capitalist economy the credit supply and investment decisions are independent of saving decisions; and 2) to show that Schumpeter's analysis provides many arguments that make it possible to justify the importance of the elements that characterize the institutional-evolutionary approach.
\end{abstract}

Keywords: saving, credit, investment, development, Schumpeter

JEL Classification Codes: E21, E22, G20, O10

Mainstream economic theory underlines the close relation between saving decisions and credit supply. The significance of this relationship can be explained by considering the behavior of a single economic agent who saves when he chooses not to use part of his income for the purchase of consumer goods. The decision to save translates into the supply of credit when our agent decides not to hide his unconsumed income under the mattress and instead chooses to deposit his savings with a bank or to purchase bonds or shares issued by a firm. In these cases he assigns his unconsumed income to agents, the firms, who need purchasing power in order to increase the stock of capital goods, i.e., to carry out investments. Mainstream economic theory deems that this causal sequence also applies at a macroeconomic level: the saving decisions of all the households determine the credit supply and thus the investment flow carried out by all firms.

The author is an Associate Professor of Macroeconomics and Monetary Economics at Università degli Studi dell'Insubria, Varese, Italy (e-mail address: gbertocco@eco.uninsubria.it). He would like to thank Nicolò De Vecchi for his helpful comments on the first draft of the paper, and the two anonymous referees for their stimulating comments. 
This paper has two objectives: 1) to highlight the theoretical limits of this causal sequence on the basis of the arguments developed by Schumpeter, who instead maintains that in a capitalist economy the credit supply and investment decisions are independent of saving decisions; and 2) to show that Schumpeter's analysis provides many arguments that make it possible to justify the importance of the elements that characterize the institutional-evolutionary approach. The paper is divided into two parts. In the first part, the arguments used under the mainstream theory to justify the causal link between saving decisions, credit supply and investment decisions are summarized. In the second part, the alternative analysis elaborated on the basis of the arguments developed by Schumpeter is presented.

\section{First Part: Saving, Credit and Investments According to the Mainstream Theory}

The causal link between saving decisions, credit supply and investment decisions is a feature that joins the contemporary mainstream theory and the classic and neoclassical theories. ${ }^{1}$ A detailed reconstruction of this causal sequence from the point of view of the history of economic thought does not fall within the aims of this paper; instead, the focus shall be put on some aspects of the classical and neoclassical theory on which the mainstream contemporary theory of saving is founded. The first section shall be devoted to the classical theory, using the analysis of Adam Smith as a reference point; the second, to the neoclassical theory and in particular the theory of Böhm-Bawerk. In the third part, Cannan's credit theory is presented and finally, in the fourth section, it is shown that the theoretical elements elaborated by the classical and neoclassical theory are still very much present in the contemporary mainstream theory.

\section{The Classical Theory: The Analysis of Adam Smith}

According to the classical theory, saving is the key element that explains how an economic system develops. Adam Smith ([1776] 1904) states that the level of development depends on the number of productive workers present in the system. He defines as productive, any worker who is involved in the production of goods sold at a price that makes it possible to obtain a surplus over the value of the means of subsistence consumed by the worker. The unproductive workers are instead those who are involved in the production of services that satisfy the needs of the higher classes and do not produce any surplus. The development process, according to Smith, consists in the continuous increase in the number of productive workers made possible by the accumulation of capital fostered by the flow of savings from the capitalists. Smith considers an economy in which capital is made up of consumer goods that capitalists transfer to the productive workers; we can assume, for example, that workers consume only corn and therefore corn is the product and capital of this economy. Corn production realized in a certain period represents the constraint on the amount of capital, the greater the amount of corn that becomes capital, i.e., that is 
destined for giving means of subsistence to the productive workers, the greater the production of corn that will be carried out in the subsequent period.

Let us suppose that in a certain period $(\mathrm{t}), 60$ productive workers have produced an amount of product that makes it possible in the subsequent period, given the characteristics of the productive work, to employ 100 workers, either productive or unproductive. The total production that will be achieved in the period $(t+1)$ depends on the number of productive workers employed. Let us assume that the capitalists, who having paid in advance the wages of the productive workers in the period $(t)$, have at their disposal the production achieved, decide to employ in the period $(t+1)$ again 60 productive workers, and to use the remaining resources for the employment of 40 unproductive workers. In this case we would get in $(t+1)$ the same level of production obtained in the previous period, and all the surplus used to remunerate the unproductive workers would, according to Smith's definition, be consumed; there would be no saving and no growth would be registered. If, alternatively, the capitalists had decided to use the entire surplus to employ new productive workers, then in the period $(t+1)$ they would have employed 100 productive workers obtaining a greater income than in the previous periods and thus a higher profit. In this case the capitalists would have realized a savings flow equal to 40 wage units, which would have given rise to an equivalent increase in capital.

Napoleoni (1970) observes that Smith's definition of development can be understood if we consider the historical context within which it was formulated, characterized by the passage from the upper class society in which surplus was destined exclusively to satisfy higher class consumption, to a capitalist society characterized by the process of accumulation fostered by saving decisions. The absence of saving condemns the high-class society to stagnation, while the process of capital accumulation transforms the increase in the population into an increase in incomereceiving workers instead of in an increase in poor people with no work or income; this explains Smith's view that every spendthrift is a public enemy and every parsimonious person, a public benefactor.

Smith's “corn economy" highlights an important aspect of the classical analysis that consists of identifying decisions to save, with decisions to invest. The decision of capitalists to save coincides with the decision to expand the amount of capital, i.e., with the decision to invest; the capitalist who saves is the same agent who invests; Say's law, in the "corn model" is automatically satisfied (Bridel 1987a; 1987b).

Hollander (1972) expresses some doubts about the appropriateness of representing Smith's theory of development by means of the "corn model," since this model overlooks fixed capital as a productive factor, and, furthermore, because it considers just one good, it neglects the system of prices and therefore the presence of money, elements that Smith considers in his analysis. There certainly is some basis to this observation, but that does not alter the fact that the "corn model" has the advantage of presenting in a rigorous manner the fundamental conclusions of Smith about the causal analysis that links the concepts of saving, investment and development. Moreover, it is Smith ([1776] 1904) himself who underlines that the presence of money does not alter the conclusions of the corn model. In fact, he 
observes that if at the end of the period $(\mathrm{t})$ the capitalists received an income in money instead of in corn, they would always find themselves facing the same choice: to use their monetary income to pay for the services of unproductive workers, or to save some of it by increasing the use of productive workers in order to obtain a profit.

\section{The Neoclassical Theory: The Analysis of Böhm-Bawerk}

We can highlight two elements of the neoclassical theory that are relevant in order to define the causal relation between saving decisions, credit supply and investment decisions. The first regards the definition of capital; the neoclassical theory considers explicitly the capital goods as a productive instrument distinct from labor. Secondly, the neoclassical theory considers explicitly the phenomenon of the dissociation between saving decisions and investment decisions: the agent that saves is not necessarily the agent who decides to expand his own capital endowment.

Böhm-Bawerk notes that goods are not produced only through labor, but they are also made using tools that in turn were produced by means of labor. The final goods are thus produced by means of a roundabout process that adds together the labor incorporated in the instruments used with the labor directly applied in the production. ${ }^{2}$ He emphasizes that unlike labor "capital cannot be an originary source of goods, since it is itself the fruit of nature and of labor" (Böhm-Bawerk [1884] 2005, 350).

Böhm-Bawerk illustrates these concepts with a famous example that is applied to the world of Robinson Crusoe whose survival depends on fishing. Let us assume that at first Crusoe just gathers the fish that the tide leaves on the beach; in this phase, production is realized only through labor. He could, however, expand the future production of fish if he decided to dedicate part of his work day to making a fishing rod, fishing net or even a boat. In such a case Robinson Crusoe's saving would consist in subtracting work time from the direct production of fish in order to build tools that would enable him to increase future production. Böhm-Bawerk ([1884] 2005, 273) underlines that the incentive to accumulate capital derives from the fact that an indirect production process is more productive than a process that uses only labor. "It is an elementary fact of human experience that time consuming roundabout methods of product are more productive." And this greater productivity constitutes the origin of the interest that he defines as "[t]he revenue which is derived from capital ..." ( Böhm-Bawerk [1884] 2005, 5).

Moreover, he considers explicitly the phenomenon of the dissociation between saving and investments and he provides an effective example regarding a primitive society of fishermen.

Let us imagine ... a tribe of people who live by fishing and who are entirely without capital. They catch their fish on the seashore by seizing with their bare hands such fish as are stranded in the pools left behind by the receding tide. A workman of this tribe catches and consumes 3 fish a day. If he had a boat and net he could catch 30 fish a day instead of 3 . But 
he cannot construct those implements because their construction would cost him a month's time and labor, and during that interval he would have nothing to live on. (Böhm-Bawerk [1884] 2005, 280-281)

The situation of our fisherman could improve considerably if someone were in a position to lend him sufficient fish to keep him alive in the period in which he is building the boat. In this case, due to the greater production of fish obtained with the boat, he can undertake to repay the loan and pay a premium constituted by the loan interest.

Now someone lends him 90 fish on condition that he promise to pay back 180 fish one month later. Our man agrees to the transaction, provides his subsistence out of the borrowed fish for one month and in the meantime constructs a boat and net with which in the following month he catches 900 fish instead of 90 . From these he cannot only repay the stipulated amount of 180 fish but also retain a sizable net gain for himself. (BöhmBawerk [1884] 2005, 281)

By explicitly considering the separation of saving and investment decisions, it is possible to highlight the relation between saving decisions and supply of capital or credit; the interest rate constitutes the price of capital and its fluctuations guarantee the equilibrium between savings and investments.

If we compare the example of Böhm-Bawerk with Smith's "corn economy," we can observe that in both cases an economy that produces just one good is considered: fish or corn; and in both cases, the accumulation of capital is preceded by a saving decision, that is by a renunciation to consume part of the production. In the case of Smith, the corn saved becomes capital when it is used to increase the number of productive workers involved in the production of corn; however, in the case of Böhm-Bawerk, the saved fish becomes capital when it permits the production of instrumental goods that will be used jointly with labor. In the case of Smith, the increase in the production that follows the accumulation of capital is determined by the productivity of labor, while in the case of Böhm-Bawerk this is brought about by the greater productivity of the roundabout methods. These differences, however, must not mask the close continuity that exists between the two theories; both point out that the saving decisions constitute the necessary premise for the accumulation of capital and the increase in production.

The express consideration of the dissociation between saving and investment decisions constitutes the necessary premise for the introduction of financial intermediaries. If, thanks to the boats, in our primitive society a good number of fishermen are able to catch a quantity of fish greater than what they consume, one of them could get an idea to build a structure to conserve the fish over time. This agent might not limit himself to just conserving the fish, but indeed might loan it in exchange for an interest. In this case, our society of fishermen shall have its "bank." The neoclassical theory states that the presence of banks does not modify the nature 
of credit compared with an economy in which savers directly finance those who wish to accumulate capital; banks are mere intermediaries, the real creditor is the saver. A clear illustration of this view is provided by Cannan.

\section{The Meaning of Bank Deposits Under the Neoclassical Theory}

In 1921, Cannan wrote an important article with the objective of refuting the thesis that was gaining ground, according to which banks are able to create ". . . thousands of millions of pounds by lending something which did not before exist to borrowers, who proceed to pay it to other people, who in their turn deposit it in the banks, and who could not have so deposited it unless the banks had lent" (Cannan 1921, 32). He deems the traditional theory perfectly valid, according to which "[t]he banker was a man or a collection of men who undertook to keep money safely for its owners until they wanted it, and who made the business pay by lending out a good deal of this money to other people who wanted temporary loans" (Cannan 1921, 28).

Cannan developed his thesis by observing that the nature of bank deposits is analogous to that of deposits having as objects a real good, such as for example the deposit of a bag at the cloakroom. ${ }^{4}$ He acknowledges that there are two differences between bank deposits and the deposit of things for safe custody. In the first place, in the case in which one deposits a bag in the railway cloakroom, the depositor expects to get his own bag back and not just any bag similar to his. Secondly, the depositor also expects that no one will use his bag. These two conditions, Cannan notes, do not apply in the case of money and bank deposits as money is a perfectly homogenous good. In the case of money, the depositor expects to get the same amount of money back and he doesn't care if the notes he gets back are the same ones he lodged with the bank. Moreover, Cannan remarks that the perfect homogeneity of money makes depositors' drop their objections about the use to which the bank puts the money; the fact that the bank can lend the cash received explains why the depositor doesn't pay anything for the conservation of the money but actually receives a remuneration on the deposits. According to Cannan, these differences do not modify the nature of bank deposits compared to the deposit of things for safe custody; the two phenomena have in common the fact that neither the bank nor the cloakroom attendant can lend more than what has been deposited.

There is nothing in [these differences] between money and other goods to suggest that the person with whom money is deposited can lend out more than he possesses in his own right plus what is deposited with him. The most abandoned cloakroom attendant cannot lend out more umbrellas or bicycles than have been entrusted to him, and the most reckless banker cannot lend out more money than he has of his own plus what he has of other people's. (Cannan 1921, 30) 
Cannan's analysis fits perfectly with the causal sequence that, according to the classical and neoclassical theories, links savings, investments and economic development. Equating bank deposits with deposits of things for safe custody means, in fact, to highlight that the depositor forgoes using goods that he produced by selling them to other agents who will be able to earn an income from these goods that will allow them to pay interest to the saver-depositor, as happens in the example of BöhmBawerk's fisherman.

\section{Mainstream Contemporary Theory}

The elements of classical and neoclassical theory regarding the causal sequence between saving and investment, and the role of the banks that we described in the previous paragraphs were totally assimilated by contemporary mainstream theory. The literature on growth theory that developed starting from the fundamental work of Solow (1956) shares the vision that the consumption and saving decisions households make, condition the accumulation of capital. Barro and Sala-i-Martin (2004) point out that all the models elaborated by contemporary theory assume that households' saving decisions determine the growth of the economy. ${ }^{5}$ This causal sequence is confirmed in numerous empirical analyses (see for example: Feldstein and Horioka 1980; Cadoret 2001; Chakrabarti 2006).

Furthermore, mainstream theory, in line with Cannan's analysis, considers banks as mere intermediaries and the credit market simply as a reflection of the saving and investment decisions. This implies that in order to elaborate an explanation of how the economic system works it is sufficient to specify saving and investment decisions, leaving aside the credit market. This point has been well explained by, for example, McCallum (1989) who introduces his Monetary Economics text by making explicit the reasons why he looks at the money market, completely leaving aside the credit market. He observes that this decision:

rests basically on the fact that in making their borrowing and lending decisions, rational households (and firms) are fundamentally concerned with goods and services consumed or provided at various points in time. They are basically concerned, that is, with choices involving consumption and labor supply in the present and in the future. But such choices must satisfy budget constraints and thus are precisely equivalent to decisions about borrowing and lending - that is, supply and demand choices for financial assets. . . . Consequently, there is no need to consider both types of decisions explicitly. . . . it is seriously misleading to discuss issues in terms of possible connections between "the financial and real sectors of the economy", to use a phrase that appears occasionally in the literature on monetary policy. The phrase is misleading because it fails to recognize that the financial sector is a real sector. (McCallum 1989, 29-30) 
Recently this theoretical view has been challenged in numerous studies that maintain that the presence of an evolved financial system is an important factor capable of influencing the rate of growth of the economy. However, these studies continue to describe a growth process that depends on the saving decisions that influence the investment decisions and thus the process of capital accumulation. The role of the financial system is to make the transformation of savings into investments possible by allocating the saved resources to the most productive firms. Chou (2007), for example, maintains that it is necessary to abandon the assumption that characterizes traditional growth models, according to which investment always equals saving, as this presupposes the presence of a perfectly efficient financial system.

In general, the intermediation process will not be completely efficient. Unless the financial sector is highly sophisticated and well developed, not all the savings of individuals will be transformed into productive funds that firms can use to finance investment in new plant and machinery. In particular, some risk-averse savers will continue to hold liquid but unproductive assets unless offered a sufficient variety of financial products. As an extreme example, in some poor countries, villagers sometimes hide their savings under their pillows, where they cannot be accessed by potential borrowers. Therefore instead of assuming that $I=S$, where $S$ is aggregate savings, I specify: $I=\varepsilon S$, where $0<\varepsilon<1$ measures the efficiency of financial intermediation. (Chou 2007, 80)

Hence, the role of the financial system is to ensure that a) the greatest proportion of saving is devoted to investments; and b) savings are used for the most productive investments. This analysis does not challenge the causal relation between saving decisions, credit supply and investment decisions (see for example, King and Levine 1993; Levine 1997; 2002; 2004; Wurgler 2000; Stulz 2001; Gorton and Winton 2002; Wachtel 2003; Capasso 2004; Fergusson 2006).

\section{An Alternative Analysis of the Relation Between Saving and Credit}

In this second part, a different analysis of the relation between saving and credit shall be presented, elaborated on the basis of arguments developed by Schumpeter. In the first section Schumpeter's critique of Cannan's theory is set out; the second section is dedicated to the loanable funds theory that shares some common features with Schumpeter's theory. Finally, the third section highlights the more significant aspects of this alternative analysis.

\section{Schumpeter's Critique of Cannan}

Schumpeter states that the traditional theory considers credit as a phenomenon independent of the presence of banks: 
[for a] typical economist, writing around 1900 ...credit is quite independent of the existence or non-existence of banks and can be understood without any reference to them. . . . The public is . . . the true lender. Bankers are nothing but its agents, middlemen who do the actual lending on behalf of the public and whose existence is a mere matter of division of labor. . . . They add nothing to the existing mass of liquid means, though they make it to do more work. (Schumpeter 1954, 1113)

He takes Cannan's theory as a reference, in order to set out his critique of the traditional theory; he criticizes Cannan's thesis, noting that there is a fundamental difference between bank deposits and deposits involving real goods. Whoever deposits an object renounces using that object until the moment it is returned; he shall get a claim that will allow him to obtain the return of the object deposited, but this claim cannot of course perform the same function as the object deposited. This is not true in the case of the bank deposit; in fact, in this case, the depositor receives from the bank a claim that he can use as a means of payment and that therefore performs the same function as gold coins.

As Professor Cannan put it ... "If cloakroom attendants managed to lend out exactly three-quarters of the bags entrusted to them . . . we should certainly not accuse the cloakroom attendants of having 'created' the number of bags indicated by the excess of bags on deposits over bags in the cloakroom." Such were the views of 99 out of 100 economists.

But if the owners of those bags wish to use them, they have to recover them from the borrower who must then go without them. This is not so with our depositors and their gold coins. They lend nothing in the sense of giving up the use of their money. They continue to spend, paying by check instead of by coin. And while they go on spending just as if they had kept their coins, the borrowers likewise spend "the same money at the same time". Evidently this phenomenon is peculiar to money and has no analogue in the world of commodities. No claim to sheep increases the number of sheep. But a deposit though legally only a claim to legal-tender money, serves within very wide limits the same purposes that this money itself would serve. (Schumpeter 1954, 1113-4) ${ }^{6}$

The presence of banks profoundly alters the nature of credit and the relation between saving and credit $^{7}$; credit becomes an independent phenomenon from saving decisions. Schumpeter stresses that banks create more or less perfect substitutes of money at the moment in which someone deposits money with them, but we can observe that banks do not create money only at the moment in which they receive deposits. In a world in which their liabilities are used as a means of payment, banks can finance an agent by granting him a line of credit, that is, by authorizing him to issue checks up to a certain amount. ${ }^{8}$ 
Schumpeter, in the 1940s, believed that Cannan's theory had been abandoned and that most economists had accepted the new theory, albeit with difficulty. ${ }^{9}$ This conviction seems to be contradicted by the reality of the second half of the twentieth century. The mainstream contemporary theory, as we have seen, continues to consider saving decisions as the factor that determines the credit supply and investment decisions, and to represent banks as intermediaries, completely neglecting Schumpeter's teaching. This situation can probably be explained by the fact that in the first decades of the twentieth century a theoretical approach, the loanable funds theory, was developed, which while recognizing the capacity of the banks to create money, held that the process of bank money creation did not modify in a significant way the structure of the economic system compared with what was described in Smith's "corn economy" or in the example of Böhm-Bawerk's fishermen's island.

\section{The Loanable Funds Theory}

The loanable funds theory is linked to Wicksell, who between the end of the nineteenth century and the early years of the twentieth century published some works where he analyzed the relation between rate of interest and inflation. Wicksell's objective is to explain the causes of price fluctuations. He maintains that the version of the quantitative theory of money elaborated by Ricardo is perfectly valid if it is applied to an economic system where "everybody buys and sells for cash and with money on their own, that is to say, neither commodity credits nor loans exist" (Wicksell [1898] 1969, 73). In this system, economic agents must keep cash holdings in order to be able to carry out their expenditure decisions and these holdings are proportional to the total amount they intend to spend. In an economy of this type, exogenous changes in the quantity of money trigger the variations in the price levels described by the quantitative theory of money. Wicksell holds that this explanation of price fluctuations cannot be applied to an economy in which a fiat money constituted by the bank liabilities is used. In this case, the spending decisions are carried out by using money created by the banks; the economic operators do not need to keep cash holdings to finance the demand for goods. Money becomes an endogenous variable because whoever desires money to purchase goods will be able to obtain it by getting into debt with the banks; therefore inflation cannot be caused by an exogenous variation in the quantity of money. ${ }^{10}$

Wicksell therefore recognizes, like Schumpeter, that banks can create money when they meet the firms' demand for credit, in other words he acknowledges that the presence of banks makes the credit supply independent of saving decisions. At the same time, however, Wicksell states that the presence of bank money does not change in a significant way the structure of the economic system with respect to an economy without banks. As a matter of fact he emphasizes that in order to analyze the consequences of the presence of bank money it is necessary to take as a reference the structure of an economy in which bank money does not exist. In particular, it is necessary to consider "the phenomena of capital and interest on capital, as they would appear if liquid capital, production's means of support, was in reality lent in kind, 
without the intervention of money; and only then it is possible to distinguish what modifications are in reality caused by the introduction of money" (Wicksell, [1898] 1969, 84).

The close link between an economy without bank money and an economy characterized by the presence of banks is highlighted by the concept of the natural interest rate that Wicksell considers important for both. He defines the natural interest rate as the rate that is obtained in an economy in which capital goods are exchanged directly. ${ }^{11}$ Thus, it is the interest rate that characterizes Smith's "corn economy" or Böhm-Bawerk's fishermen's island, ${ }^{12}$ a rate that constitutes an essential element of the Wicksellian explanation of inflation. Wicksell ([1898] 1969, 78) affirms that in a pure credit economy the price levels do not depend on the gap between money demand and supply but rather on the price of money that is represented by the rate of interest that must be paid to obtain money, i.e., on the interest rate set by the banks. "A low rate of interest must lead to rising prices, a high rate of interest to falling prices" (Wicksell [1898] 1969, 78). He observes that "high" and "low" interest rates are not absolute concepts but that they must be defined in relation to a term of reference that is constituted by the natural rate of interest. A pure credit economy is characterized by the presence of two distinct markets: the credit market and the capital market, within which two different rates of interest are determined; the rate of interest on money set by the banks, and the natural rate of interest.

The monetary interest rate applied by banks does not necessarily coincide with the natural interest rate; a discrepancy between the two interest rates is possible. Wicksell ([1898] 1969, 81-82) remarks that the discrepancy between the two rates is caused by variations in the natural rate of interest, which the banks may not even realize, caused for example by events that modify the productivity of roundabout methods described by Böhm-Bawerk. Finally, Wicksell notes that the process of price fluctuations caused by the gap between interest rates cannot last long; neither the individual bank nor all the banks together can maintain the monetary rate of interest at a different level than the natural rate for long.

Concerning the subject of this paper it is important to point out that although he elaborated a theory which states that credit supply does not depend on saving decisions, Wicksell states that the presence of banks and of bank money does not alter the structure of the economic system. The natural rate of interest constitutes the nucleus around which the economy gravitates; the only consequence of the presence of banks is the inflation process determined by the discrepancy between the rate of interest set by the banks and the natural rate of interest.

In the 1930s, following Wicksell, economists such as Ohlin, Robertson and Hayek set against the Keynesian interest rate theory, one that states that the rate of interest on money is determined within the credit market. Two aspects of the analysis of these authors warrant highlighting. Firstly, they noted that there is a relation between the credit supply and demand functions and the saving and investment functions, ${ }^{13}$ even if these functions do not coincide. Robertson emphasizes this relation when he considers a succession of periods: 
I assume the existence of a period of time, to be called a "day", which is finite but nevertheless so short that the income which a man receives on a given day cannot be allocated during its course to any particular use. A man's disposable income - the income about which the question arises on any particular day as to whether it shall be "saved" or "spent" - is thus the income received not on that day but on the previous one. A man is said to be saving if he spends on consumption less than his disposable income. (Robertson 1933, 399)

Savings precede, and therefore condition investment decisions even if there is not a perfect coincidence between the two flows, since a saving decision can lead to the choice of lending or accumulating money, while an investment decision can be financed by getting into debt with savers, by using existing money or, finally, by the creation of new money. The condition of equilibrium on the loanable funds market can thus be represented by the following equation:

$$
S+\Delta M=I+\Delta H
$$

$\mathrm{S}$ stands for the savings flow, $\Delta \mathrm{M}$ the new money created by the banks, $\Delta \mathrm{H}$ the fluctuations in the cash holdings accumulated by the private operators, while I indicates the investment flows. If $\Delta \mathrm{M}$ and $\Delta \mathrm{H}$ are equal to zero the functions of credit demand and supply coincide with the saving and investment functions; furthermore, at parity of $\Delta \mathrm{M}$ and $\Delta \mathrm{H}$, a variation in the saving flow influences the monetary interest rate and investment decisions. If banks acted as simple intermediaries, collecting households' savings and transferring them to firms, the rate of interest on money would coincide with the natural rate. ${ }^{14}$

The second significant aspect of the analysis that developed in the early decades of the last century based on Wicksell's work concerns the description of the effects of the discrepancy between the monetary interest rate and the natural interest rate. This analysis points out that a discrepancy between the interest rates does not influence only the rate of inflation but it alters saving and investment decisions; for example, a situation in which the monetary interest rate is less than the natural one because of an expansionary monetary policy provokes a phenomenon of forced saving.

The policy-induced lowering of the interest rate causes the economy to react in important respects as if the additional investment funds had been made available by voluntary saving. Hence, the corresponding increase in investment in the early stages of production gets labelled with the term ... forced saving: resources are allocated . . . in accordance with greater saving even though the saving implied by such an allocation is not at all voluntary. ... (Garrison 2004, 326)

It can be observed that despite the concept of forced saving, the loanable funds theory asserts the substantial neutrality of bank money in that: a) it holds that the 
concept of a natural interest rate can be applied to an economy with bank money and that an economy of this type can thus be described by means of Smith's "corn economy" or Böhm-Bawerk's parable of the fishermen's island; and b) the neutrality of money can be obtained through a correct monetary policy that aims to maintain the monetary rate at the level of the natural one. In this case the monetary authorities will have achieved the objective of price stability and the phenomena of forced saving shall be avoided.

The loanable funds theory has profoundly influenced the mainstream monetary theory; it constitutes the theoretical foundation of the strategy adopted in recent years by the central banks of western countries, i.e., pursuing the objective of price stability through a monetary policy rule based on interest rate manoeuvre. ${ }^{15}$

\section{An Alternative Analysis}

\section{The Role of Credit in a "Capitalist Economy"}

Wicksell and Schumpeter formulate a similar explanation of the nature of deposits and bank credit, very different from that of Cannan; despite this, there is a strong difference between the two authors. Wicksell deems that the credit phenomenon is independent of the presence of banks; his analysis is based on the concept of natural interest rates that represent the starting point from which he analyzes the working of an economy with bank money. Instead, Schumpeter claims that the credit phenomenon is not at all independent of the presence of banks, and that the diffusion of bank money signals a break with Böhm-Bawerk's fisherman economy or Smith's corn economy. He acknowledges that the presence of banks and bank money is a fundamental factor in explaining the principal characteristic that distinguishes a capitalistic economy from a pure exchange economy: change. ${ }^{16} \mathrm{He}$ proposes to explain the phenomenon of change by distinguishing between growth and development. The former regards a pure exchange economy while a capitalist economy is characterized by the process of development. A pure exchange economy is one that always tends to replicate itself unchangingly, or that is in any case subject to very gradual changes that do not alter the structure of the economic system, or to changes triggered by extra-social factors like natural conditions, or by extra-economic social factors such as wars, or by consumer tastes. It is an economy in which the production decisions are influenced by consumers' preferences and in which the principle of consumer sovereignty holds.

Schumpeter states that the traditional theory is able to explain only the working of a pure exchange economy, and underlines the need to elaborate a new theory that describes the working of a capitalist economy. It is a theory based on a double heresy, "first to the heresy that money, and then to the second heresy that also other means of payment, perform an essential function, hence that processes in term of means of payment are not merely reflexes of processes in terms of goods" (Schumpeter [1912] 1934, 95). 
Banks and credit constitute an essential element in explaining the phenomenon of development that according to Schumpeter ([1912] 1934, 63) is determined by two endogenous factors, i.e., of an economic character. First, the changes taking place in production as a consequence of the innovations spawned by entrepreneurs; these innovations might consist in the realization of a new product, the adoption of a new production method, or the opening of new markets. The second key element of the process of economic development is the creation of money by banks through credit. It states that credit:

is the characteristic method of the capitalist type of society - and important enough to serve as its differentia specifica - for forcing the economic system into new channels, for putting its means at the service of new ends ... it is as clear a priori as it is established historically that credit is primarily necessary to new combinations. (Schumpeter [1912] 1934, 69. 70)

The essential role attributed to credit is due to the presence of three elements: 1) the fact that innovations are carried out especially by new men, who do not own the factors of production; 2) the full employment of productive resources; and 3) private ownership of the factors of production. Schumpeter argues that if innovations were realized by existing firms, credit would not be necessary, since, in order to realize the innovations, the entrepreneur would use the productive means already available. Credit becomes a necessary factor for development when innovations are made by new entrepreneurs who do not own means of production. He (Schumpeter [1912] $1934,79-81$ ) justifies this hypothesis by noting that the introduction of an innovation requires decisions that are completely different from those connected to economic activity in a pure exchange economy; for this reason, innovations will not normally be brought in by the persons who manage the existing firms. (We will come back to this point in the following pages.) To underline this point, Schumpeter ([1912] 1934, 74) defines entrepreneurs as only those economic agents who introduce innovations. The second factor that makes the role of credit very important is the full employment of production resources assumption. Schumpeter introduces this assumption to underline the fact that innovations are realized by withdrawing available productive resources from existing firms and allocating them to the entrepreneurs-innovators lacking means of production. For this reason, he assumes that innovations are introduced in a situation in which all the productive resources are fully utilized. ${ }^{17}$ In order to carry out innovations, therefore, a tool allowing the change of ownership and control of existing productive resources is required; this tool is credit. Banks, through the creation of bank money, transfer to the innovators-entrepreneurs the purchasing power necessary to divert the resources from their traditional uses.

By creating money to finance the innovators-entrepreneurs, the banks alter the distribution of ownership of the means of production. The instrument permitting the ownership and control of the means of production to be transferred to the innovators-entrepreneurs is the inflation triggered by the increase in the demand for 
means of production on the part of the innovators-entrepreneurs. This increase in the demand with respect to the full employment of productive resources causes an increase in the price of services enabling the innovator to divert resources from their current allocation. With inflation it is possible to generate

a shift in purchasing power among individuals and ... a transfer of means of production to those individuals to whom credits are granted by means of newly created money. . . . New men and new plans come to the forefront that otherwise would always have remained in the background. The obstacles are removed which private property places in the way of him who does not already have command over means of production. The banking world constitutes a central authority of the economy whose directives put the necessary means of production at the disposal of innovators in the productive organism. . . . The essence of modern credit lies in the creation of such money. It is the specifically capitalistic method of effecting economic progress. It gives scope to the capitalistic function of money, as opposed to its market-economy function. (Schumpeter [1917] 1956, 205-206)

Ultimately, the fundamental role of credit described by Schumpeter depends on the fact that in a capitalistic economy the ownership of means of production is private. Schumpeter ([1912] 1934, 78) argues that in a socialist economy the innovation process does not require the use of credit, given that in this system there is a central authority that decides to employ the production resources differently from the way they were previously used in order to realize the innovations.

\section{The Reasons for the Non-Neutrality of Bank Money}

Schumpeter asserts, as we have seen, that the presence of bank money is a necessary element to explain the process of change determined by the introduction of innovations that characterize a capitalist economy; an economy that is profoundly different from Smith's corn economy or Böhm-Bawerk's fishermen's island. There are two aspects that characterize these economies and that cannot be applied to the capitalist economy described by Schumpeter.

The first, concerns the assumption of a sole good being produced that can be consumed or invested. This assumption is not appropriate for describing a world characterized by innovations that also consist in the production of new goods. If we allow the possibility that new goods are produced, we are faced with the problem of establishing who decides what should be produced. A world in which a sole good is produced can be considered as an extreme example of the application of the principle of consumer sovereignty as, evidently, this sole good is what guarantees the survival of consumers. Schumpeter holds that the principle of consumer sovereignty can be applied to a pure exchange economy ${ }^{18}$ but not to a capitalist economy in which consumers' choices are conditioned by the decisions of entrepreneurs and of the banks; ${ }^{19}$ Schumpeter illustrates this point very effectively: 
Railroads have not emerged because any consumers took the initiative in displaying an effective demand for their service in preference to the services of mail coaches. Nor did the consumers display any such initiative wish to have electronic lamps or rayon stocking, or to travel by motorcar or airplane, or to listen to radios, or to chew gum. The great majority of changes in commodities consumed has been forced by producers on consumers who, more often than not, have resisted the change and have had to be educated up by elaborate psychotechnics of advertising. (Schumpeter ([1939] 1964, 47)

Schumpeter therefore attributes to banks a very different role from the one specified under the traditional theory; in fact, he emphasizes that in a capitalist economy, by financing innovations through the creation of new money, banks condition the process of change in the economic system characterized by the production of new goods. The presence of banks makes the occurrence of phenomena that cannot be found in a static economy possible. In particular, by creating money, banks allow new players to make innovations by taking control of the productive resources away from existing firms; in the absence of banks and credit money this would not be possible because the existing firms would continue to use the productive resources in the traditional productive processes and they would not have any reason to transfer them to new agents who intend to alter the existing productive equilibriums. ${ }^{20}$

The second aspect that distinguishes the capitalist economy described by Schumpeter is the fact that the innovations that characterize this economy highlight the dimension of uncertainty. In an economy that produces just one good the entrepreneurs are sure they will sell everything they produce, as the good produced is that which guarantees the survival of consumers; it could be Smith's corn or BöhmBawerk's fish. ${ }^{21}$ This hypothesis cannot be applied in the case of Schumpeterian innovations. The entrepreneur that makes a new good is not at all sure that he will be able to sell, making a satisfactory profit, everything he produces because the innovation alters the existing world and this makes it very difficult to predict the reaction of consumers to the new proposal. Schumpeter believes that the introduction of innovations requires competencies that are very different from those necessary to run an existing business because the innovator-entrepreneur must make decisions without having clear points of reference that allow him to forecast the consequences of his decisions. ${ }^{22}$ For this reason, innovations are brought in by "new men" capable of making decisions in conditions of uncertainty.

The presence of bank money and the phenomenon of credit characterize an economy that is markedly different from the one described by traditional theory. It is an economy that is subject to a continuous process of change due to the introduction of innovations, in which the principle of consumer sovereignty does not hold and in which the dimension of uncertainty assumes considerable weight. The working of such an economy cannot be described by taking as a reference a static economy without innovations, that which Schumpeter defines a pure exchange economy; he 
emphasizes this point when he observes that Wicksell's concept of the natural interest rate has no relevance when one wants to explain the working of a capitalist economy:

The necessity of reconciling a nonmonetary theory with obvious facts of the sphere of money and credit is, in particular, responsible for the idea that there are two kinds of interest rates, a "natural" or "real" one which would also exist in a barter economy and which represents the essence of the phenomenon, a permanent net return from physical means of production, and a monetary one, which fundamentally is but the former's reflex in the monetary sphere ... The roots of this idea reach very far into the past...Its role in the thought of our own time is due to the teaching of Knut Wicksell . . . For us, however, there is no such thing as a real rate of interest, except in the same sense in which we speak of real wages . . . the money market with all that happens in it acquires for us a much deeper significance than can be attributed to it from the standpoint just glanced at. It becomes the heart, although it never becomes the brain, of the capitalist organism. (Schumpeter [1939]1964, 101)

It is not possible to apply concepts that are appropriate for an economy characterized by the absence of bank money to a capitalist economy. As we have seen, Schumpeter believes that to explain the working of a capitalist economy it is necessary to elaborate a theory based on the heresy that money is not a neutral variable since its presence constitutes a necessary element to explain the phenomenon of development. An important implication of the non-neutrality of money theory elaborated by Schumpeter is in the importance given to the monetary nature of capital, profits and interest rates. He notes that in such an economy the meaning of these variables can be defined only starting from the presence of banks and bank money. Schumpeter affirms that the definition of capital as a set of goods used as means of production, the definition used by Böhm-Bawerk, cannot be applied to a capitalist system because it is a definition that can be adapted to any economic system. ${ }^{23}$ Schumpeter's definition reflects the importance he assigns to bank money in the development process; in fact, he identifies capital with the purchasing power made available to entrepreneurs so that they can carry out their innovations "[w]e shall define capital . . . as that sum of means of payments which is available at any moment for transference to entrepreneurs" (Schumpeter, [1912] 1934, 122).

By specifying the monetary nature of capital, Schumpeter ([1939] 1964, 80) affirms that profits cannot be considered as the result of the productivity of a particular productive factor. He (Schumpeter [1912] 1934, 154) considers profits as a phenomenon present only in a capitalist economy in which innovations, financed by money created by the banks, invest entrepreneurs with a monopolistic power that allows them to fix a price that causes a monetary surplus over costs.

Moreover, Schumpeter highlights the monetary nature of the interest rate; it does not constitute the reward for giving up consumption because the supply of credit does not coincide with the saving. Schumpeter derives the monetary nature of the 
interest rate from the monetary nature of capital. He criticizes the theories that consider the interest rate as a reward for abstinence from consumption or as the compensation for a production factor (Schumpeter [1912] 1934, 183; Schumpeter [1939] 1964, 100), and emphasizes (Schumpeter [1912] 1934, 195) that the transaction that generates interest is not the exchange of goods between savers and firms, but the exchange of money taking place on the credit market between banks and firms.

\section{Schumpeter and the Role of Banks}

As we have seen in the previous pages, the bank money that is created by the banks allows innovator-entrepreneurs to take control of the productive resources away from the existing firms and inflation is the tool that enables us to modify the distribution of the existing productive resources. What makes the process described by Schumpeter different from forced saving described by the loanable funds theory is the presence of innovations. The concept of forced saving is applied to a world in which just one good is produced. In this case, the production process can be described by simply considering the level of production and its composition in terms of quotas of consumption and investment and the presence of bank money makes the relation between saving and investment more complicated without altering the structure of the system. Bresciani-Turroni (1936a) for example, notes that in the presence of bank money saving and investments are not realized simultaneously, but the flow of investments can anticipate the saving flow. ${ }^{24}$ He hypothesizes, following BöhmBawerk, that the investment goods must be realized through labor and thus, in an initial phase it is necessary for the entrepreneurs to procure an amount of consumer goods that will make it possible to maintain the workers involved in the production of investment goods. This demand can be financed through credit. In the second phase, the saving flow arises allowing the entrepreneurs to extinguish the debts contracted for the acquisition of the capital goods. ${ }^{25}$

It is most significant that in order to illustrate his arguments, Bresciani-Turroni uses the example of the railways, ${ }^{26}$ the same example employed by Schumpeter to describe the process of change that characterizes a capitalist economy. BrescianiTurroni does not use the concept of innovation and therefore he analyzes only the repercussions of the decision to build the railways on the total amount of investments and saving; in contrast, Schumpter forces us to consider new aspects concerning the construction of the railways. First, he emphasizes that the introduction of the railways did not result from the demands of consumers, but was the fruit of a decision by entrepreneurs and banks that could radically alter the structure of the economic system. By facilitating the connections between different regions, railways foster exchanges, permit the opening of new markets, and determine the influx of new products; these changes can bring existing firms to crisis point, and more in general, radically affect the standards of living in society.

Secondly, Schumpeter's analysis leads us to notice that the decision to make the railways was taken in conditions of uncertainty: the entrepreneurs-innovators only 
had a vague idea of the economic consequences of their decisions. If they had done nothing more than build a new model of boat that was more efficient than the previous one, they would have been able to predict with ease the greater quantity of fish that they could have obtained. In the case of the railways, the situation is different; the entrepreneur must be able to imagine the characteristics of the new world in which fishing is no longer the only productive activity because, for example, thanks to the railway the fishermen can easily reach a new region where other goods are produced. Finally, Schumpeter observes that the introduction of an innovation such as the railways can give rise to a profit as a result of the monopolistic power that the entrepreneur-innovator enjoys. We have to underline that following Schumpeter, this profit cannot be defined in terms of goods - Smith's corn or Böhm-Bawerk's fish - but only in terms of money because profit only has a monetary nature.

Schumpeter attributes a very different role to the banks from the one specified by mainstream theory. The role of banks is to create money and to decide whether or not to finance innovation projects whose effects will be produced at an uncertain future date. Schumpeter emphasizes that banks do not act on behalf of a particular group of economic agents, but on behalf of society as a whole, since they do not lend resources owned by a specific group of agents. ${ }^{27} \mathrm{He}$ underlines that the entrepreneur-innovator does not risk his own resources but he acquires the means of production thanks to the purchasing power created by the banks. It is the bank that assumes the risk of the innovation and, through it, the entire community that accepts the redistribution of the ownership of the means of production, caused by the banks' decisions. ${ }^{28}$

Schumpeter underlines the importance of the role of the banks by affirming that they have the same function as the central authority in a socialist economy. In a socialist economy the means of production are publicly owned and so it is the central authority that decides how to use the available productive factors. When such authority decides to produce a new good, it orders a certain quantity of productive factors from a given sector to be collected and used in the new activity. In a capitalist economy in which the means of production are privately owned, the role of the central authority is carried out by the banks who offer the entrepreneur-innovator the purchasing power to enable him to use the productive factors, diverting them away from the uses to which they were previously destined (Schumpeter [1939] 1964, 86). Awareness of the banks' social function of selector of innovating entrepreneurs leads Schumpeter ([1939] 1964, 90-91) to specify the features of the banker's behavior. In the first place, the banker must know how to assess the characteristics of the investment project to be carried out and the personality of the entrepreneur. Secondly, as the banks act on behalf of society and not of particular agents, they must stay independent of the firms and political power. ${ }^{29}$ Schumpeter ([1939] 1964, 91) underlines that if the banks behave improperly the consequences can be disastrous; the wrong decisions of the banks are "sufficient to turn the history of capitalism evolution into a history of catastrophes." 30

Schumpeter's fears about the disastrous consequences of bad behavior of banks are justified by the particular role of selector of innovating entrepreneurs that they carry out. In the world described by the traditional theory, in which there are no 
innovations and just one good is produced, the function of banks would be just that of entrusting the saved resources to the most productive entrepreneurs, for example, the ones that are able to build fishing boats. In this case, the conclusions about their behavior would be immediate. The banks must show that they are able to correctly evaluate the most productive uses of the saved resources; otherwise, the savers would not have any reason to bear the cost of the intermediation and the incompetent banks would be expelled from the market.

Schumpeter's remarks about the disastrous effects of the improper behavior of banks have also been taken up in some contemporary studies. We can consider two examples. The first is the analysis carried out by Minsky (1975; 1980; 1982), who had been a student of Schumpeter, that highlights the crucial role of the banks in explaining the instability of capitalism. Minsky's analysis of the financial nature of the instability of capitalism is closely connected to the observations made by Keynes and Schumpeter on the importance of bank money, credit, and uncertainty. Keynes ([1937] 1973) maintained that in the presence of uncertainty the evaluation criteria used to make economic decisions are subject to sudden changes. We can also say that the banks' evaluation criteria can change suddenly causing considerable instability in the economic system. Minsky $(1980 ; 1982)$ explains that the alternating phases of boom and bust are due to changes in a banks' criteria in appraising firms' investment projects. The adoption of permissive criteria drives boom phases, encouraging firms to increase their borrowing and, consequently, their debt repayment commitments; this creates the conditions for a crisis when events prevent firms from honoring their repayment obligations. There is an endogenous tendency toward instability, since, in normal periods a firms' ability to repay their loans constitutes a confirmation of the validity of their forecasts, and induces banks to believe that they applied excessively rigid criteria in evaluating the firms' requests for credit. The upshot of this is that firms will be encouraged to consider more risky investment projects, and banks will be led to adopt less rigid selection criteria. This behavior transforms a normal situation into a boom fuelled by speculative investments.

It is my belief that the use of the Schumpeterian concept of innovation can bolster the explanation of the alternating boom and bust phases. The introduction of innovations is a phenomenon capable of raising profit expectations owing to the conviction that a new era replete with unprecedented opportunities, arising out of unfolding events, is afoot. ${ }^{31}$ The anticipation of a new era founded on innovations can render any project, even the most unlikely one, worthy of financing, as long as it is connected with the new innovating revolution. ${ }^{32}$ Moreover, the financial system can encourage the speculative process by creating new financial instruments, thereby triggering an explosion in the financial structure with respect to the real one. ${ }^{33}$

The second example is the analysis carried out by Rajan and Zingales (2003a; 2003b; 2003c). They note that banks may fail to fulfil the function described by Schumpeter, and become an obstacle to the process of development. Schumpeter points out that the entrepreneurs' innovations break the existing equilibrium and thus trigger the reaction of the agents who feel threatened by the effects of the innovation. Hence, the entrepreneurs must overcome: “. . . the reaction of the social 
environment against one who wishes to do something new ..." (Schumpeter [1912] 1934, 86-87). Rajan and Zingales (2003a, 23-24) observe that a financial structure characterized by the presence of banks that grant credit to firms on the basis of a lasting relationship over time may become an obstacle to the introduction of innovations by new entrepreneurs as the banks tend to protect the interests of the existing firms threatened by innovations (for a critical analysis of Rajan and Zingales' thesis, see, Bertocco 2008).

\section{The Role of Saving}

In contrast with mainstream theory, Schumpeter states that the process of development of a capitalist economy is independent of saving decisions: innovations are financed by money created by banks and not by saving. Naturally also in a capitalist economy, the economic agents save, that is they decide not to use part of their income to demand goods; the problem then arises of how to define what type of relation manifests itself in this economy between credit supply, saving decisions and investment decisions.

We can specify this relation by introducing two hypotheses. The first one is to assume that the innovations are introduced by means of investment decisions; Schumpeter assumes that the stock of means of production is given and that innovations are introduced by subtracting the control of these means of production from the existing firms through the credit granted to the entrepreneurs-innovators. Let us assume instead that the innovations are introduced by means of the demand for investment goods. In this case, investment decisions do not consist merely by adding to the existing stock of capital goods new units of capital goods identical to the existing ones, but we can consider them as the tool through which firms launch new products on the market, or modify the productive process through which the existing goods are realized, or even open new markets. ${ }^{34}$ The second hypothesis is the introduction of the Keynesian principle of effective demand. These assumptions enable us to describe the process of money creation by distinguishing two phases that correspond to the distinction between finance and funding introduced by Keynes.

The entrepreneur when he decides to invest has to be satisfied on two points: firstly, that he can obtain sufficient short term finance during the period of producing the investment; and secondly, that he can eventually fund his short-term obligations by a long-term issue on satisfactory conditions. (Keynes 1937c, 217)

In the first phase banks finance firms by creating new money. Banks and firms are the main actors in this phase; the supply of credit does not depend on saving decisions but on the decisions taken by banks. The investments financed by the banks determine an increase in income according to what is laid down in the Keynesian income theory. Dalziel $(1996 ; 2001)$ describes the different phases of the income multiplication process that arise out of the expansion in the demand for 
investment goods financed by the creation of new bank money. In the second phase, wealth owners step in; the new money created by banks is added to the existing money and the saving flow generated by investment decisions increases the public's wealth. The second phase is the one in which firms and households express their decisions about the composition of their debts and their wealth; in this phase the conditions are created for the wealth owners to accept to hold the money created by the banks. We can distinguish the two stages of the money creation process by specifying two distinct markets: the money market and the credit market. The credit market is made up of flow variables: the credit demand function reflects the behavior of firms. This demand for liquidity can be considered as a demand for credit since it is expressed by actors who: (a) do not have liquidity; and (b) who, when they obtain the cash, undertake to pay it back at a fixed future date. By specifying the credit demand function, we distinguish the firms' demand for liquidity to finance investment decisions from the demand for bank money, which instead reflects the portfolio decisions of wealth owners. As for the credit supply function, the main conclusion that emerges from Schumpeter's analysis is that the supply of credit does not depend on saving decisions but depends on the decisions taken by banks and that it is independent of the savings flow. The money market is made up of stock variables; the money demand function describes the portfolio decisions of wealth owners, while the money supply corresponds to the sum of the stock of money available at the beginning of the period and the flow of money created by the banks to finance the firms' investment decisions. ${ }^{35}$

Finally, we can highlight a problem that arises out of Schumpeter's analysis of the role of banks. The emphasis that he places on the monetary function of banks, that is on their capacity to create means of payment to finance innovations, contrasts with the conclusions of many recent studies that point out that innovations are financed by financial institutions such as venture capitalists. These studies highlight the fact that bank credit does not constitute a very suitable instrument for financing the particularly risky investment projects, which if successful, could yield high returns. Indeed, in these cases the banks would have to apply excessively high interest rates, above the limits that are set by law against usury, and which, if they could be applied, would constitute an intolerable burden for firms. On the contrary, the venture capitalists finance the firms by underwriting shares, counting more on the possible gain in capital account to be obtained by the sale of shares rather than on the dividends (see for example, Gompers 1995; Berger and Udell 1998; Mason and Harrison 1999; Carpenter and Petersen 2002; Rajan and Zingales 2003a; 2003b; 2003c; Perez 2007).

If it is recognized that in contemporary economies innovations are not financed by banks but above all by agents such as venture capitalists, then we must ask if these agents are also able to carry out a monetary function similar to the one that characterizes the banks. At first glance, it would seem that the banks have a particular characteristic that distinguishes them from the other financial institutions, i.e., the fact that their liabilities are used as a means of payment; thus banks can finance a firm by authorizing it to issue checks, whereas other financial institutions lend up what 
they are able to collect. Unlike what happens for the banks, the action of the nonbank financial institutions seem to presuppose the existence of savers and firms. These institutions collect financial resources from the savers and they lend them to firms. An economic system based on non-bank financial institutions, therefore, seems to possess characteristics that are coherent with the traditional theory of credit according to which saving decisions constitute the original phenomenon that determines the credit supply and thus investment decisions. According to this theory the financing of innovations with money collected from savers has no effect on the level of the aggregate demand since the greater demand on the part of the innovatorentrepreneur offsets the lower demand on the part of the savers.

It is possible to show that this conclusion is not well-founded by using the arguments, employed by Schumpeter to criticize Cannan's theory, as described above. As we have seen, Schumpeter notes that there is a fundamental difference between bank deposits and the deposits that have a real good as an object. Whoever deposits an object forgoes using that object up to the moment in which it is returned. He shall obtain a receipt that will allow him to obtain the return of the deposited object, but this receipt certainly cannot carry out the function of the deposited object. This is not true in the case of the bank deposit. In fact, in this case, the depositor obtains a receipt that he can use as a means of payment, so therefore Schumpeter concludes, in the case of money the depositors do not in fact give up consumption because they can purchase goods using as a means of payment their credit instruments with the banks.

These considerations allow us to observe that even if venture capitalists do not create new money, their action cannot be analyzed within the framework of the neoclassical theory that sets against the greater demand for goods by the players who obtained the financing, the lower demand for goods on the part of whoever underwrites the liabilities of the intermediary. Let us suppose, in fact, that the venture capitalists obtain the necessary funds to finance the entrepreneur-innovators from agents who decide not to consume part of their income and to underwrite quotas of a venture capital firm. Following Schumpeter's reasoning, we can observe that the savers who decide to finance a venture capitalist do not forgo demanding goods at all as at any moment they can sell their quotas in the venture capital firm and thus use these quotas as a means of payment. We can say therefore that in the presence of a financial system that allows financial assets to be liquidated with ease, venture capitalists, while they do not create bank money, do create new liquidity when they collect money by selling their quotas to savers. Moreover, we must note that the wealth owners who underwrite shares in exchange for their money do not give up demanding goods, but they simply alter the composition of their wealth. The income saved, which is added to the stock of households wealth, heightens demand for financial assets without putting any limitation on the firms' investment decisions that are financed by means of the creation of new money or by the employment of existing money. 


\section{Schumpeter and the Institutional-Evolutionary Approach}

Schumpeter's analysis contains significant arguments that make it possible to justify the importance of many elements that characterize the institutionalevolutionary approach. These elements, as well as Schumpeter's contributions, are recalled schematically in this section.

1. The importance of change. The central theme that the institutional-evolutionary approach deals with is explaining the process of economic change (see for example: North 1990; 2005; Acemoglu, Johnson and Robinson 2005; Hodgson 2006; 2007; O'Hara 2007; Potts 2007; Nelson 2007). And, as we have seen, this is the central theme of the analysis formulated by Schumpeter, who approaches this matter by distinguishing the phenomenon of growth that is typical of a real exchange economy from the phenomenon of development, founded on innovations and credit, that characterizes a capitalist economy.

2. The need for a new theory. Schumpeter notes that the traditional theory is only capable of explaining the phenomenon of growth and underlines the need to elaborate a new theory that explains the phenomenon of development. And, this is a widespread conviction among the supporters of the institutional-evolutionary approach. North, for example, states that "[t]he economic paradigm - neo-classical theory - was not created to explain the process of economic change. We live in an uncertain and ever changing world that is continually evolving in new and novel ways. Standard theories are of little help in this contest" (North 2005, vii).

Schumpeter on one side, and the supporters of the institutional-evolutionary approach on the other, maintain that the fundamental reason why the neoclassical theory is unable to explain the process of economic change is the fact that this theory is based on equilibrium rather than change. The traditional theory is not, therefore, able to explain the characteristics of a process of change that does not drive the economic system toward the ideal equilibrium in which, as Schumpeter notes, production decisions are aimed at satisfying consumer needs, and in which money is only a means of exchange. ${ }^{36}$ Hodgson, for example, states that "[t]he general processes of Darwinian evolution are not necessarily progressive ... It is another common misunderstanding to regard Darwinism as proclaiming an automatic progression towards a superior state" (Hodgson 2006, 22).

3. The importance of money. We have seen that Schumpeter maintains that the new theory necessary for explaining the process of economic change must be based on a heresy concerning the definition of the role of money. In a capitalist economy money is not a mere means of exchange but it is the instrument that makes possible the phenomenon of development. Schumpeter, as we have recalled, highlights the importance of money, underlining the monetary nature of the concepts of capital, profit and interest; that is, he notes that these concepts have meaning only if we consider the presence of bank money and therefore of the credit phenomenon. 
The institutional-evolutionary approach considers money as a fundamental institution. We can distinguish two different ways of conceiving money as an institution. The first is associated with the analysis of the process of the emergence of money elaborated by Menger (1892). Menger considers the presence of money as the unintended result of a selection process based on the degree of saleability of commodities, carried out by the members of a society. He underlines that this process of emergence of money is determined by the costs of the barter economy caused by the "double coincidence problem." This way of conceiving the functions of money is coherent with the thesis that the institutions are instruments that allow the problems linked to the presence of imperfections, such as asymmetric information, to be overcome, or the transaction costs to be reduced. The function of institutions is to ensure that a market economy achieves the results, in terms of allocation and level of utilization of resources, that, according to the economic theory, characterize an economy without imperfections and without transaction costs. ${ }^{37}$

This is certainly not Schumpeter's approach. According to Menger, the presence of money does not change the structure of the economic system that remains substantially a barter economy. In contrast, as we have seen, Schumpeter elaborates a different way of conceiving the role of money. He states that the presence of bank money makes possible phenomena that do not occur in a barter economy. ${ }^{38}$

4. Heterogeneous agents. Schumpeter abandons the hypothesis of perfectly homogenous agents and states that the process of change that characterizes a capitalist economy is conditioned by the decisions of two categories of agents: the entrepreneurs-innovators and the bankers. Schumpeter's analysis is thus based on the "principle of heterogeneous agents" that is typical of the institutional-evolutionary approach. This principle: ". . . states that there are multiple roles played by agents... due to asymmetric distribution of power and resources" (O'Hara 2007, 12; see also Wunder 2007).

Arena and Gloria-Palermo $(2007,203)$ deem that there is substantial continuity between Menger, von Wieser and Schumpeter, in that they all consider: ". . . the existence of two groups of agents associated with two types of rationality." Menger describes the process of emergence of money by distinguishing between innovators and imitators, while von Wieser distinguishes between leaders and masses; Arena and Gloria-Palermo believe that these classifications are analogous to the one between entrepreneur-innovators and imitators introduced by Schumpeter. In my opinion there are two differences between Schumpeter's position and that of Menger and von Wieser. The first is the fact that for Schumpeter the presence of heterogeneous agents is a necessary condition to explain the process of economic change, while according to Menger and von Wieser it serves only to explain the presence of money. Second, in Schumpeter's case, the principle of heterogeneous agents does not only regard the distinction between innovators-entrepreneurs and imitators, but it also concerns the category of bankers whose function is to create money in order to ensure that the entrepreneur-innovators have control of the necessary resources to realize the innovations. 
5. Uncertainty. Schumpeter underlines, as we have seen in the previous pages, that the presence of bank money and the phenomenon of credit are features of an economy that is subject to a continuous process of change due to the introduction of innovations and in which the dimension of uncertainty assumes considerable weight. The relation between the presence of bank money, the process of change and the dimension of uncertainty is another aspect shared with the institutional-evolutionary approach (see for example, O'Hara 2007; Ferrari-Filho and Camargo Conceição 2005).

Schumpeter offers an important example of how institutions such as bank money can generate uncertainty. The relation between institutions and uncertainty is at the basis of the analysis of the process of economic change elaborated by North. $\mathrm{He}$ notes that the objective of reducing uncertainty can constitute a good reason for driving the economic agents who are able to do so to introduce a specific institution, but he adds that the institutions do not push the economic system towards an equilibrium characterized by the absence of uncertainty as they themselves generate other forms of uncertainty.

The alteration of institutions that has led to the reduction in the uncertainties of the physical environment has created the complex human environment which has produced a whole new (and in many cases still unresolved) set of uncertainties. The revolution in technology of the past several centuries has made possible a level of human well-being of unimaginable proportions as compared to the past, but it also has produced a world of interdependence and universal externalities, and in consequence a whole new set of uncertainties. The law merchant, patent law, the institutional integration of distributed knowledge, the creation of a judicial system, have been important parts of efforts making markets more efficient in developed countries. And they are leading us into an unknown world of future uncertainties. (North 2005, 20-21)

\section{Conclusions}

The aim of this paper is to highlight the limits of the mainstream theory according to which saving decisions determine the credit supply, investment decisions, and therefore the process of economic development. In the first part, the common elements found in the saving theory elaborated by the classical, neoclassical and contemporary theories were specified.

The first element of the alternative analysis based on the arguments detailed by Schumpeter in his critique of Cannan is the emphasis on the fact that the banks are not simply intermediaries, but that they finance firms by creating new means of payment. This thesis is analogous to that of Wicksell and the supporters of the loanable funds theory; where Schumpeter and Wicksell clearly diverge is in the specification of the consequences of the diffusion of bank money. Wicksell and the supporters of the loanable funds theory, believe that the spread of bank money does not 
modify the structure of the system with respect to a barter economy; the Wicksellian concept of the natural interest rate testifies to the close link between the two economies. The only consequence linked to the presence of banks is the fact that the monetary interest rate set by the banks can assume a value different from the natural rate; this discrepancy can generate cyclical fluctuations characterized by inflation and the phenomena of forced saving.

Wicksell's thesis and that of the supporters of the loanable funds theory applies to an economy that Schumpeter would define as static, i.e., an economy whose only form of change regards the quantity of the only good produced: Smith's corn economy or the fishing-based economy of Böhm-Bawerk. Schumpeter observes that what distinguishes a capitalist economy from the economy described by the traditional theory is the phenomenon of change determined by two endogenous factors: innovations and bank credit. These two elements give rise to a profoundly different economic system from the one described in the loanable funds theory. In the first place, it is a world in which the principle of consumer sovereignty does not hold; as a matter of fact, innovations are not introduced through pressure from consumers, but instead they reflect the decisions of entrepreneur-innovators and the banks that finance them. In the second place, the capitalist economy described by Schumpeter is characterized by the presence of uncertainty defined in a Keynesian sense: the innovator-entrepreneur, and the banks that finance him, make their decisions without having the possibility of predicting in probabilistic terms the future outcome of their decisions. Hence, it is an economy in which the effects of the banks' decisions cannot be described using the reductive concept of forced saving. Schumpeter underlines the fracture between a capitalist economy and a real exchange economy, abandoning the Wicksellian concept of natural interest rates and highlighting the monetary nature of concepts of capital, profit and interest. Schumpeter's analysis leads us to state that in a capitalist economy credit and investment are variables that are independent of the saving flow. Previously we described the causal relation that links credit, investment decisions and saving decisions, specifying two phases in the process of money creation and distinguishing between the money market and the credit market. It was noted that investments can be financed not only through the creation of new money but also through the employment of existing money that can be made available to entrepreneurs-innovators thanks to the action of agents other than the banks such as the venture capitalists. At last, we recalled the elements of Schumpeter's analysis that make it possible to justify the importance of many points of the institutional-evolutionary approach.

\section{Notes}

1. As Bresciani-Turroni observes: "The truth is that, though the outcome of saving is normally in any case the same - namely, the stream of saving transforms itself into a stream of new intermediate goods which later results in an increase of consumable income - the ways leading to this result are different" (1936a, 11).

2. Böhm-Bawerk defines capital: “. . . as consisting of a complex of produced means of acquisition, that is to say, a complex of goods which come into existence as the result of a previous process of production, and which are destined, not for immediate consumption, but for acquisition of future goods" ([1884] 2005, 5). 
3. Taylor (2000) makes up some tales that describe the effects of the presence of a bank in a "subsistence (but otherwise idyllic) island society."

4. 'There is nothing really mysterious about the nature of banking 'deposits'. The term 'deposit' seems very appropriate as the name of the verb which we use to describe the action of placing an article with some person or institution for safe custody. We 'put things down' anywhere - our spectacle-case and our gloves, and often fail to find them again, and to 'deposit' a thing is etymologically nothing more than to put it down; but the latinity of the word seems to give it a tinge of solemnity suggestive of the rites we go through when we entrust our bag to the cloakroom clerk instead of 'putting it down' on the platform" (Cannan 1922, 28-29).

5. "Given that [in a closed economy] saving must equal investment, $\mathrm{S}(\mathrm{t})=\mathrm{I}(\mathrm{t})$, it follows that the saving rate equals the investment rate. In other words, the saving rate of a closed economy represents the fraction of GDP that an economy devotes to investment" (Barro and Sala-i-Martin 2004, 25). "A greater willingness to save . . and a better technology raise the growth rate" (Barro and Sala-i-Martin 2004, 297).

6. Schumpeter had already set out these considerations in his The Theory of Economic Development. "While I cannot ride on a claim to a horse, I can, under certain conditions, do exactly the same with claims to money as with money itself, namely buy" (Schumpeter [1912] 1934, 97).

7. The presence of banks "alters the analytic situation profoundly and makes it highly inadvisable to construe bank credit on the model of 'existing funds' being withdrawn from previous uses by an entirely imaginary act of saving and then lent out by their owners. It is much more realistic to say that the banks 'create credit', that is, that they create deposits in their act of lending, than to say that they lend the deposits that have been entrusted to them. And the reason for insisting on this is that depositors should not be invested with the insignia of a role which they do not play. The theory to which economists clung so tenaciously makes them out to be savers when they neither save nor intend to do so; it attributes to them an influence on the 'supply of credit' which they do not have. The theory of 'credit creation . . . brings out the peculiar mechanism of saving and investment that is characteristic of full fledged capitalist society and the true role of banks in capitalist evolution. . . this theory therefore constitutes a definite advance in analysis" (Schumpeter 1954, 1114).

8. This point has been well described, for example, by Hicks who distinguishes three different phases in the evolution of the banks: "There are three distinct stages in the evolution of banking, ... (in) the first . . . the bank is no more than a financial intermediary. . . . People lend to the banker, altogether he pays a lower rate of interest than that which he charges. . . . because they do not have the knowledge, which he has acquired in building up his business, by which they can find for themselves such safe and profitable investments as he is finding. ... The second stage of banking evolution comes when the banker realizes that it is safe for him, or usually safe for him, to accept money on deposit, subject to withdrawal on demand or at short notice. . . The importance of this second stage is largely that it leads (and often very rapidly leads) to the third. . . This is the point at which deposits in banks, withdrawable deposits, are made transferable; either by cheque, which is an instruction to a bank to transfer an existing deposit, or by note - which is in effect a cheque payable to bearer, having the guarantee of the bank behind it, without reference to the depositor against whose deposit it was originally issued. This is vital; for it is at this point that the banks becomes able to create what is in effect money. When it makes a loan, it does not have to hand out the old 'hard' money; all it does is to exchange claims. Against the obligation of the borrower, to repay by some fixed date, it provides an obligation of its own, which is transferable upon demand, and for that reason has a money quality. The money which it lends is money that it itself creates" (Hicks 1969, 94. 96). See also: Kindleberger 1984; Hicks 1989; Goodhart 1989.

9. "[I]t proved extraordinarily difficult for economists to recognize that bank loans and bank investments do create deposits . . . even in 1930, when the large majority had been converted and accepted that doctrine as a matter of course, Keynes, rightly felt it to be necessary to re-expound and to defend the doctrine at length, and some of its most important aspects cannot be said to be fully understood even now" (Schumpeter 1954, 1114).

10. "If we imagine this system developed everywhere to such perfection as it can be said to have attained already in the big banking centres, by means of cheques and a clearing system, and even somewhat further, then all purchases, and in fact all business transactions, could be effected without material coinage simply by means of entries in the books of the banks. . . Here the quantity theory seems, at least on the surface of it, to have lost every inch of ground, because when . . . neither coins nor notes 
are used in the conduct of business, there is no need for any metallic cash holding, . . . However much 'money' is demanded in the banks, they can pay it out without danger of insolvency, since they do nothing about it, but enter a few figures in their books to represent a loan granted or a deposit withdrawn. .." (Wicksell, [1898]1969, 75-76).

11. ". . . if capital was lent in kind, there would undoubtedly develop, through the supply of and the demand for available capital, a certain rate of interest on the lending market, which would be the natural rate of interest on capital in the strictest sense" (Wicksell [1898] 1969, 84).

12. Wicksell $([1898] 1969,84)$ in fact quotes Böhm-Bawerk among the economists that influenced the elaboration of his theory of capital and interest rate; for a definition of the natural rate of interest in terms of the "corn model." See Bindseil 2004.

13. "That the relation between the curves referring to savings and investment and those referring to credit is close should be obvious. If a man plans to save, must he not either plan to invest or to lend?" (Ohlin 1937, 425).

14. Robertson defines the natural rate of interest as: "... the rate at which the new lendings which can be absorbed by industry per atom of time and the new available savings for atom of time are equal" (Robertson 1934, 651).

15. The European Central Bank for instance states that: "In the long term, real interests rates are determined mainly by real factors, inter alia by the rate of productivity growth and by households' preferences as to whether to spend on consumption sooner rather than later. In the short term, however, real interest rates can be influenced by monetary policy. . . The most intuitive and straightforward determinants of the natural real interest rate are those anchored in households' decisions on their pattern of consumption and saving over time. For example, a decrease in the value households attach to future consumption relative to current consumption ... will, other things being equal, encourage households to bring forward consumption and reduce saving. In this situation the equilibrium real interest rate must rise in order to ensure, in the aggregate, that savings remain equal to investment. . . . For firms, fast productivity growth implies higher returns on physical investment. This stimulates investment demand. To generate sufficient savings to meet this investment demand, the natural real rate of interest rate must rise" (ECB 2004, 57-58). On this point see: Woodford 2003.

16. "Unlike other economic systems, the capitalism system is geared to incessant economic change. Its very nature implies recurrent industrial revolutions which are the main sources of the profit and interest incomes of entrepreneurs and capitalists and supply the main opportunities for new investments. . . Whereas a stationary feudal economy would still be a feudal economy, and a stationary socialist economy would still be a socialist economy, stationary capitalism is a contradiction in terms" (Schumpeter, 1943, 178).

17. "[W]henever we are concerned with fundamental principles, we must never assume that the carrying out of new combinations takes place by employing means of production which happen to be unused. In practical life, this is very often the case. There are always unemployed workmen, unsold raw materials, unused productive capacity, and so forth. . . . but great unemployment is only the consequence of non-economic events - as for example the World War - or precisely of the development which we are investigating. In neither of the two cases can its existence play a fundamental role in the explanation, and it cannot occur in a well balanced circular flow from which we start" (Schumpeter ([1912] 1934, 67). On this point see, Oakley (1990).

18. In this economy "the productive process have in general no real leader, or rather the real leader is the consumer. The people who direct business firms only execute what is prescribed for them by wants or demand and by the given means and methods of production. Individuals have influence only in so far as they are consumers, only in so far as they express a demand" (Schumpeter [1912] 1934, 21).

19. "II]nnovations in the economic system do not as a rule take place in such a way that first new wants arise spontaneously in consumers and then the productive apparatus swings round through their pressure. We do not deny the presence of this nexus. It is, however, the producer who as a rule initiates economic change, and consumers are educated by him if necessary. ... Therefore, while it is permissible and even necessary to consider consumers' wants as an independent and indeed the fundamental force in a theory of circular flow, we must take a different attitude as soon as we analyse change" (Schumpeter ([1912] 1934, 65).

20. This transfer is made possible thanks to the credit. "This is done by credit, by means of which one who wishes to carry out new combinations outbids the producers in the circular flow in the market for the required means of production. And although the meaning and object of this process lies in a 
movement of goods from their old towards new employments, it cannot be described entirely in terms of goods without overlooking something essential, which happens in the sphere of money and credit and upon which depends the explanation of important phenomena in the capitalist form of economic organisation, in contrast to other types" (Schumpeter, [1912] 1934, 71).

21. This statement implies acceptance of the assumption that the welfare of consumers grows with the growth in the quantity of corn or fish consumed; it is an implicit hypothesis in all the growth models elaborated by the mainstream contemporary theory in which it is assumed that a sole good is produced and that higher growth rates increase social wellbeing.

22. "E[very step outside the boundary of routine has difficulties and involve a new element ... outside these accustomed channels the individual is without those data for his decisions and those rules of conduct which are usually very accurately known to him ... Of course he must still foresee and estimate on the basis of his experience. But many things must remain uncertain, still others are only ascertainable within wide limits, some can perhaps only be 'guessed'. In particular this is true of those data which the individual strives to alter and those which he wants to create. . . Carrying out a new plan and acting according to a customary one are things as different as making a road and walking along it. . . As military action must be taken in a given strategic position even if all the data potentially procurable are not available, so also in economic life action must be taken without working out all the details of what is to be done. Here the success of everything depends upon intuition, the capacity of seeing things in a way which afterwards proves to be true, even though it cannot be established at the moment, and of grasping the essential fact, discarding the unessential, even though one can give no account of the principles by which this is done" (Schumpeter [1912] 1934, 84-85). It can be observed that when Schumpeter describes the behavior of the innovatorentrepreneur, the views he expresses are similar to those of Keynes on the impossibility of predicting the future effects of economic decisions on the basis of observations on the past; on this point see, Bertocco (2007).

23. "[C]apital defined so as to consist of goods belongs to every economic organisation and hence is not suitable for characterising the capitalistic one. ." Schumpeter ([1912] 1934, 117); and again: "Capital is neither the whole nor a part of the means of production - original or produced. Nor is capital a stock of consumption goods" Schumpeter ([1912] 1934, 123).

24. "[N]ew investment ... need not take place simultaneously with saving, or follow more or less closely upon it, but will in many cases precede saving. Investment is then financed not with savings but with bank credit, which anticipates future saving" (Bresciani-Turroni 1936b, 165).

25. "The essential fact is that, in order that new investment goods be produced, it is necessary to dispose of a certain flow of consumers' goods, which will maintain labour during the process of production. Either these goods are supplied by the savers themselves, and in this case no short time credit is needed; or the new investment goods are produced in anticipation of future saving, through diverting part of the existing stream of consumption goods to other directions; and in this case the subsequent saving does not result in the creation of additional free capital in the form of consumption goods, but merely renders it possible to the entrepreneurs to pay off their debts" (Bresciani-Turroni 1936a, 21 22).

26. "When it is anticipated that, for instance, a railway will be constructed during the period $\mathrm{BC}$, the preparatory work will already begin, say, during the period OA. Coal producers get credit in order to pay their workers, and the credits are repaid when the coal enterprises sell the coal to firms which produce raw steel. The latter will also buy coal, iron ore, and services of labour with credits, which in turn will be repaid when the steel is sold. The volume of short term credit thus swells as production proceeds from the higher to the lower stages. When during the period $\mathrm{BC}$ funds begin to be raised by the promoters who plan to construct a railway, there are already locomotives, car, rails, sleepers, building materials awaiting a purchaser. They embody a certain volume of bank credit which will be released, and will become again available for production either on the same or on other lines, as soon as the new investment goods are exchanged against savings" (Bresciani-Turroni 1936a, 20-21).

27. After having underlined that the entrepreneur-innovator can carry out the innovations only thanks to the credit obtained by the banks and thus only if he becomes a debtor, Schumpeter states: "The entrepreneur is also a debtor in a deeper sense, as may be emphasised here: he receives goods from the social stream -again in principle - before he has contributed anything to it. In this sense he is so to speak a debtor of society. Goods are transferred to him, to which he has not that claim which alone gives access to the national dividend in other cases" (Schumpeter [1912] 1934, 102). 
28. "The entrepreneur is never the risk bearer ... The one who gives credit comes to grief if the undertaking fails. ... But even if the entrepreneur finances himself out of former profits ... the risk falls on him as capitalist or as possessor of goods, not as entrepreneur. Risk-taking is in no case an element of the entrepreneurial function. Even though he may risk his reputation, the direct economic responsibility of failure never falls on him"(Schumpeter [1912] 1934, 137).

29. "If (banks) are to fulfil the function which has above been illustrated with the analogy with that socialist board which examines and passes upon the innovations envisaged by the executive, they must first be independent of the entrepreneurs whose plans they are to sanction or to refuse. This means, practically speaking, that banks and their officers must not have any stake in the gains of enterprise beyond what is implied by the loan contact. . . But another kind of independence must be added to the list of requirements: banks must also be independent of politics. Subservience to government or to public opinion would obviously paralyze the function of that socialist board. It also paralyzes a banking system. This fact is so serious because the banker's function is essentially a critical, checking, admonitory one. Alike in this respect to economists, bankers are worth their salt only if they make themselves thoroughly unpopular with governments, politicians, and the public" ( Schumpeter [1939] 1964, 92).

30. Schumpeter considers the bank/industry collusion as an element that can destroy entrepreneurial activity and innovations. On this point see for example, De Vecchi (1995, ch. 8).

31. Perez $(2002 ; 2007)$ uses the Schumpeterian concepts of innovation and credit to explain the occurrence of boom phases marked by phenomena of speculation, financial innovation and "irrational exuberance."

32. With the introduction of innovations: "Opportunities grow explosively. Innumerable entrepreneurs will offer their projects to the also growing number of financiers. If they seem to follow the new paradigm, all projects, good and bad, honest and crooked, are likely to have access to the required funds" (Perez 2007, 792).

33. ". . . financial capital . . . will now innovate in ways that turn the stock market into a casino, decoupling from the real economy and building extraordinary paper mountains. It will speculate with whatever is at hand, from gold to real estate, and will also invent all sort of bonds and derivatives, inverted pyramids and even less legitimate schemes. High profit expectations will be kept alive by the financial wizards in a growing atmosphere of 'irrational exuberance"' (Perez 2007, 793).

34. Schumpeter himself underlines the relation between investment decisions and innovations when he criticizes the static structure of Keynes's General Theory: “. . . reasoning on the assumption that variations in output are uniquely related to variations in employment imposes the . . assumption that all production functions remain invariant. Now the outstanding feature of capitalism is that they do not but that, on the contrary, they are being incessantly revolutionized. The capitalism process is essentially a process of change of the type which is being assumed away in this book, and all its characteristic phenomena and problems arise from the fact that it is such a process. A theory that postulates invariance of production functions may, if correct in itself, be still of some use to the theorists. But it is the theory of another world and out of all contact with modern industrial fact, unemployment included. No interpretation of modern vicissitudes, 'poverty in plenty' and the rest, can be derived from it. ... Since Mr. Keynes eliminates the most powerful propeller of investment, the financing of changes in production functions, the investment process in his theoretical world has hardly anything to do with the investment process in the actual world ..." (Schumpeter 1936, 794).

35. In Bertocco (2005) some examples of models that describe the credit market and the money market are specified.

36. ". . . money only performs the function of a technical instrument, but adds nothing new to the phenomena. To employ a customary expression, we can say that money thus far represents only the cloak of economic things and nothing essential is overlooked in abstracting from it" (Schumpeter [1912] 1934, 51).

37. Merton and Bodie offer a useful example of this approach applied to the analysis of financial institutions: ". . . the particular institutions and organizational forms that arise...are an endogenous response to minimize the costs of transaction frictions and behavioural distortions in executing the financial functions common to every economy." They emphasize that the presence of institutions does not change the resource allocations and asset prices: "Neoclassical theory is approximately valid for determining asset prices and resources allocations. ... Neo-institutional and behavioural theories are centrally important in analyzing the evolution of institutions including market instruments and 
financial intermediaries, but are unlikely to provide significant and stable explanations of asset prices and resources allocations" $(2005,6)$.

38. Schumpeter $(1954,278)$ classifies monetary theories into two categories: real analysis and monetary analysis. In the first category he includes those theories that consider money only as an instrument meant to facilitate trading without having any effect on economic processes; these theories state the money neutrality principle. In the second category, Schumpeter inserts those theories that consider money an essential element in understanding how the economic system works.

\section{References}

Acemoglu, Daron, Simon Johnson and James Robinson. "Institutions as a Fundamental Cause of Longrun Growth.” In Handbook of Economic Growth, edited by Philippe Aghion and Steven Darlauf, pp. 385-472. Amsterdam: Elsevier North Holland, 2005.

Arena, Richard and Sandye Gloria-Palermo. "Evolutionary Themes in the Austrian Tradition: Menger, von Wieser and Schumpeter on Institutions and Rationality." In The Evolution of Economic Institutions, edited by Geoffrey Hodgson, pp. 198-210. Cheltenham: Edward Elgar, 2007.

Barro, Robert and Xavier Sala-i-Martin. Economic Growth, Second Edition. Cambridge, MA: The MIT Press, 2004.

Berger, Allen and Gregory Udell. "The Economics of Small Business Finance: the Roles of Private Equity and Debt Markets in the Financial Growth Cycle." Journal of Banking EF Finance 22 (1998): 613-673.

Bertocco, Giancarlo. "The Role of Credit in a Keynesian Monetary Economy." Review of Political Economy 17 (2005): 489-511.

—. "The Characteristics of a Monetary Economy: a Keynes-Schumpeter Approach." Cambridge Journal of Economics 31, 1 (2007): 101-122.

—. "Finance and Development: Is Schumpeter's Analysis Still Relevant?” Journal of Banking $\mathcal{E}$ Finance 32 (2008): 1161-1175.

Bindseil, Ulrich. Monetary Policy Implementation. Oxford: Oxford University Press, 2004.

Bridel, Pascal. "Saving Equal Investment." In The New Palgrave Dictionary of Economics, edited by John Eatwell, Murray Milgate and Peter Newman, pp. 246-248. London: The Macmillan Press, 1987a.

- Cambridge Monetary Theory. London: The Macmillan Press, $1987 \mathrm{~b}$.

Böhm-Bawerk, Eugen. Capital and Interest. Reprinted in Capital Theory, edited by Christopher Bliss, Avi Cohen and Geoffrey Harcourt, pp. 119-138. Cheltenham: Edward Elgar, [1884] 2005.

Bresciani-Turroni, Costantino. "The Theory of Saving I. The Forms of the Saving Process." Economica 3, 9 (1936a): 1-23.

—_. "The Theory of Saving II. Disequilibrium Between Saving and Investment." Economica 3, 10 (1936b): $162-181$.

Cadoret, Isabelle. “The Saving Investment Relation: a Panel Data.” Applied Economics Letters 8 (2001): 517 520 .

Cannan, Edwin. “The Meaning of Bank Deposits.” Economica 1 (1921): 28-36.

Capasso, Salvatore. "Financial Markets, Development and Economic Growth: Tales of Informational Asymmetries." Journal of Economic Surveys 18, 3 (2004): 267-292.

Carpenter, Robert. and Bruce Petersen. "Capital Market Imperfections, High-tech Investment, and New Equity Financing.” The Economic Journal 112, (February 2002): F54-F72.

Chakrabarti, Avik. "The Saving-Investment Relationship Revisited: New Evidence From Multivariate Heterogeneous Panel Cointegration Analyses." Journal of Comparative Economics 34, (2006): 402-419.

Chou, Yuan. "Modelling Financial Innovation and Economic Growth: Why the Financial Sector Matters to the Real Economy." Journal of Economic Education Winter (2007): 78-91.

Dalziel, Paul. "The Keynesian Multiplier, Liquidity Preference, and Endogenous Money." Journal of Post Keynesian Economics 18 (1996): 311-331.

- Money, Credit and Price Stability. London: Routledge, 2001.

De Vecchi, Nicolò. Entrepreneurs, institutions and economic change. Aldershot: Edward Elgar, 1995.

European Central Bank (ECB). “The Natural Real Interest Rate in the Euro Area." ECB Monthly Bulletin May (2004): 57-69. 
Feldstein, Martin and Charles Horioka. "Domestic Saving and International Capital Flows." The Economic Journal 90 (1980): 314-329.

Fergusson, Leopoldo.. "Institutions for Financial Development: What Are They and Where Do They Come From?" Journal of Economic Surveys 20, 1 (2006): 27-69.

Ferrari-Filho, Fernando and Octavio Augusto Camargo Conceição. "The Concept of Uncertainty in Post Keynesian Theory and in Institutional Economics." Journal of Economic Issues 39, 3 (2005): 579-594.

Garrison, Roger. "Overconsumption and Forced Saving in the Mises-Hayek Theory of the Business Cycle." History of Political Economy 36, 2 (2004): 323-349.

Gompers, Paul. "Optimal Investment, Monitoring, and the Staging of Venture Capital." The Journal of Finance 50 (1995): 1461-1489.

Goodhart, Charles. Money, Information and Uncertainty. London: Macmillan, 1989.

Gorton, Gary and Andrew Winton. "Financial Intermediation." NBER Working Paper Series 8928. 2002.

Hicks, John. A Theory of Economic History. Oxford: Oxford University Press, 1969.

- A Market Theory of Money. Oxford: Oxford University Press, 1989.

Hodgson, Geoffrey. Economics in the Shadow of Darwin and Marx. Cheltenham: Edward Elgar, 2006.

_. "The Revival of Veblenian Institutional Economics." Journal of Economic Issues 41, 2 (2007): 325-340.

Hollander, Samuel. The Economic Theory of Adam Smith. Toronto: University of Toronto Press, 1972.

Keynes, John Maynard. "The 'ex ante' Theory of the Rate of Interest." The Economic Journal. In J.M. Keynes, The Collected Writings, vol XIV, pp. 215-223. London: Macmillan Press, [1937] 1973.

Kindleberger, Charles. Financial History of Western Europe. London: George Allen \& Unwin, 1984.

King, Robert and Ross Levine. "Finance and Growth. Schumpeter Might be Right." The Quarterly Journal of Economics 108, 3 (1993): 717-737.

Levine, Ross. "Financial Development and Economic Growth: Views and Agenda." Journal of Economic Literature June (1997): 688-726.

_ . "Bank-based or Market-based Financial Systems: Which is Better?" Journal of Financial Intermediation 11 (2002): 398-428.

"Finance and Growth: Theory and Evidence." NBER Working Paper Series, 10766. September 2004.

Mason, Colin and Richard Harrison. "Financing Enterpreneurship: Venture Capital and Regional

Development." In Money and the Space Economy, edited by Ron Martin, pp. 157-184. Chichester, West Sussex: John Wiley \& Sons, 1999.

McCallum, Bennet. Monetary Economics. Theory and Policy. New York: Macmillan Publishing Company, 1989.

Menger, Karl. "On the Origin of Money." The Economic Journal 2 (1892): 239-255.

Merton, Robert and Zvi Bodie. "Design of Financial Systems: Towards a Synthesis of Function and Structure." Journal of Investment Management 3, 1 (2005): 1-23.

Minsky, Hyman. John Maynard Keynes. New York: Columbia University Press, 1975.

- "Money, Financial Markets and the Coherence of a Market Economy." Journal of Post Keynesian Economics 3 (1980): 21-31.

—. Can 'It' Happen Again? Essays on Instability and Finance. Armonk, NY: M.E. Sharpe, 1982.

Napoleoni, Claudio. Smith, Ricardo, Marx. Torino: Boringhieri, 1970.

Nelson, Richard. "Institutions and Economic Growth: Sharpening the Research Agenda." Journal of Economic Issues 41, 2 (2007): 313-323.

North, Douglass. Institutions, Institutional Change and Economic Performance. Cambridge: Cambridge University Press, 1990.

—. Understanding the Process of Economic Change. Princeton: Princeton University Press, 2005.

O'Hara, Phillip. "Principles of Institutional-Evolutionary Political Economy - Converging Themes from the School of Heterodoxy." Journal of Economic Issues 41, 1 (2007): 1-42.

Ohlin, Bertil. "Alternative Theories of the Rate of Interest: Three Rejoinders." The Economic Journal 47 (1937): 423-427.

Oakley, Allen. Schumpeter's Theory of Capitalist Motion. Aldershot: Edward Elgar, 1990.

Perez, Carlota. Technological Revolutions and Financial Capital; the Dynamics of Bubbles and Golden Age. Cheltenham: Edward Elgar, 2002. 
—_. "Finance and Technical Change: a Long-term View." In Elgar Companion to Neo-Schumpeterian Economics, edited by Horst Hanusch and Andreas Pyka, pp. 775-799. Cheltenham: Edward Elgar, 2007.

Potts, Jason. "Evolutionary Institutional Economics." Journal of Economic Issues 41, 2 (2007): 341-350.

Rajan, Raghuram and Luigi Zingales. "Banks and Markets: the Changing Character of European Finance." NBER Working Paper Series, 9595. March 2003a.

_ . "The Great Reversal: the Politics of Financial Development in the Twentieth Century." Journal of Financial Economics 69 (2003b): 5-50.

- Saving Capitalism from Capitalist. New York: Crown Business Division of Random House, 2003c.

Robertson, Dennis. "Saving and Hoarding." The Economic Journal 43, (1933): 399-413.

_. "Industrial Fluctuation and the Natural Rate of Interest." The Economic Journal 44 (1934): 650-656.

Schumpeter, Joseph. The Theory of Economic Development. Cambridge, MA: Harvard University Press, [1912] 1934.

_. "Money and the Social Product." International Economic Papers 6 ([1917] 1956): 148-211.

_ . "Review of Keynes's General Theory." Journal of the American Statistical Association December (1936): 791-795.

—. Business Cycle. A Theoretical, Historical and Statistical Analysis of the Capitalist Process. New York: McGraw Hill, [1939] 1964.

—. "Capitalism in the Postwar World." In Postwar Economic Problems, edited by Seymour Harris, London: McGraw-Hill. Reprinted in: Joseph Schumpeter. Essays on Economic Topics of J. A. Schumpeter. Port Washington, New York: Kennikat Press, 1943.

—. History of Economic Analysis. New York: Oxford University Press, [1954] 1994.

Smith, Adam. An Inquiry into the Nature and Causes of the Wealth of Nations. Oxford: Oxford University Press, [1776] 1904.

Solow, Robert. "A Contribution to the Theory of Economic Growth." Quarterly Journal of Economics LXX, I (1956): 65-94.

Stulz, René. "Does Financial Structure Matter for Economic Growth? A Corporate Finance Perspective." In Financial structure and Economic Growth, edited by Asli Demirgüc-Kunt and Ross Levine, pp. 143-188. Cambridge, MA: The MIT Press, 2001.

Taylor, Lester. Capital, Accumulation and Money. Boston: Kluwer Academic Publishers, 2000.

Wachtel, Paul. "How Much Do We Really Know About Growth and Finance?" Federal Reserve Bank of Atlanta Economic Review First Quarter (2003): 33-47.

Wicksell, Knut. "The Influence of the Rate of Interest on Commodity Prices." In Selected Papers on Economic Activity, edited by Knut Wicksell. New York: Augustus M. Kelley Publishers, [1898] 1969.

Woodford, Michael. Interest and Prices. Princeton: Princeton University Press, 2003.

Wunder, Timothy. "Toward an Evolutionary Economics: the 'Theory of Individual' in Thorstein Veblen and Joseph Schumpeter." Journal of Economic Issues 41, 3 (2007): 827-839.

Wurgler, Jeffrey. "Financial Markets and the Allocation of Capital." Journal of financial Economics 58 (2000): $187-214$. 
Copyright of Journal of Economic Issues (M.E. Sharpe Inc.) is the property of M.E. Sharpe Inc. and its content may not be copied or emailed to multiple sites or posted to a listserv without the copyright holder's express written permission. However, users may print, download, or email articles for individual use. 